Article

\title{
A "Fishy Tale"? The Fisher Hugheses of Pittenweem, Fife, Scotland: Oral tradition to Documented Genealogy
}

\author{
Jenny Swanson \\ Independent scholar; jennyswansongenealogist@gmail.com; Tel.: +44-01235-536781
}

Received: 8 June 2017; Accepted: 14 July 2017; Published: 24 July 2017

\begin{abstract}
The surname HUGHES (several spelling variants) was numerous amongst the fishers recorded in 19th century censuses for Pittenweem, Fife, Scotland. A twentieth-century oral tradition in at least one HUGHES branch held that the family fished in Pittenweem for "hundreds of years". This study aimed to examine the tradition, using sound genealogical research techniques of record collection, critical assessment, comparison and analysis, and briefly sets the results in historical context. Lack of information from local vital records created some difficulties, but contextual strategies (for example collection of data for collateral relatives; analysis of baptismal records-particularly witness data-for social connections and possible occupation of baby's parents) were used as supplements. Alternative strategies proved effective. Evidence was found for fishers in every generation of this direct male line for at least 200 years, with a possible paper-trail for nearly 300 years. A wider question arises over whether the many HUGHES fishers of Pittenweem were from one biological family. Records back to the 1720s suggest this is possible, but lack of earlier paper documentation allows alternative interpretations. Two members of the wider family have had Y-DNA testing which provided a good match - it was concluded that additional samples from descendants of particular, documented, 18th century lines might resolve this issue.
\end{abstract}

Keywords: genealogy; oral traditions; inherited occupation; Scottish fishers; Hughes of Pittenweem

\section{Introduction}

Genealogical researchers soon discover the power of oral history-stories which may mutate over the years in an attenuated form of the old party game of "Whispers". There, even when the repeated "story" is brief and factual, the later version normally bears little resemblance to the original. This mutability is true of oral history also. Historical distance seems to have little relevance-family traditions within the last century may be completely false, and others referring to events three centuries ago may be substantially correct. Sometimes critical analysis shows a family tradition to be highly accurate, while in other cases it is difficult to understand how something so far from historical truth could ever have become established. But one has to allow for the ancestors who were downright liars, the enthusiastic tellers of tall tales who enjoyed every moment ... and interestingly their descendants often seem particularly reluctant to let go of the family legends. Perhaps this is because the stories were such good ones!

As a general rule of thumb, it seems that the more exotic the myth, the less likely it is to be substantially correct. Yet often there is at least an element of truth in what has become an extravagant claim, and this alone makes family legends worth investigation. Anne Powers' family tradition spoke of "an Indian princess" among ancestors-definitely a "high-status" claim. Her research revealed this ancestor was an 18th century West Indian named Priscilla (Powers 2012); See also blog http://aparcelofribbons.co.uk/). Although largely inaccurate, the legend held a kernel of useful information, and subsequent research uncovered a fascinating study of an 18th century family and 
their West Indian connections. The existence of a family tradition is an element of family history in its own right, and such traditions are always worth exploring, provided it is understood that historical reality may differ significantly.

This article describes the systematic historical analysis of a family tradition which is far from exotic - that ancestors had been employed for centuries in the difficult and dangerous work of fishing. Back in the 1940s and 1950s, a fisherman's son from Pittenweem, Fife, told his children that their male line ancestors, the HUGHES family in that village, had been fishers in the same Scottish coastal village for "hundreds of years". The "fisher HUGHESes of Pittenweem" were a well-known family in twentieth century Fife- the fact that numerous HUGHES men fished there is hardly a discovery. The duration of their fishing experience, however, may be of some interest-as may the issue of whether they constituted one biological family or several.

It has long been a popular belief, shared by many scholars, that in Scotland fishing was almost invariably a hereditary occupation - that fishers were the sons of fishers, and that fisher's sons grew up to fish (Gray 1978, p. 11; Fitzpatrick 2010, p. 36; Martin 1991, p. 13). Now that it is possible to do more detailed research into the ancestry and occupational histories of individual members of fishing communities at various dates, it can be seen that this belief about fishers may be largely true in a majority of cases, yet have numerous exceptions (Swanson 2013, Appendix F., p. 72; Swanson 2014). There is variation between different locations, and between historical periods. It is logical that this should be so, as local viability of the occupation, and availability of sons to follow their fathers, would naturally vary between regions and in different economic conditions.

How could one test the accuracy of this specific oral tradition around the fisher HUGHESes of Pittenweem? It refers to "hundreds of years": while this might simply be a euphemism for "a very long time", one would need to trace back at least 200 years in order to examine its accuracy. "Hughes family ancestors" might reasonably include collaterals, depending on how one defines "family", but for the purpose of this investigation has been defined in its most rigorous sense-the direct male line. There are therefore two strands to the issue-identification of a direct male line for at least 200 years from a fixed point, and a parallel investigation of occupation for each individual in this line. In outline, the goal was to name the father in each generation back, then find occupational records to discover whether each individual father had fished. The study raised various difficulties with the local records-in particular the scarcity of reliable references to fishers and fishing before 1841, and the challenge of identifying parentage for individuals who died before statutory death certificates appeared in 1855 (particularly when there were multiple local candidates of the same name and similar age). Despite these difficulties, a methodology was developed which enabled the direct male line in this case to be traced back at least 8 generations to the early 18th century. It was found that there was good evidence of fisher occupation in the direct male line through all these generations: this line of the HUGHES family had indeed fished in Pittenweem for over 200 years-possibly nearly 300.

\section{Methodology}

A single direct male line in one location should be straightforward to trace into the mid 19th century, as Scottish statutory records are particularly informative: birth, marriage and death certificates name both parents and give any occupations. However there were several issues around available documentation. Recorded occupations in statutory records are not always reliable, because of "status inflation": for example Robert BLACK, resident in Pittenweem around 1848-1851, was variously described by relatives as fish curer, mason (Marriages (SRP) Scotland 1867), newspaper reporter (Deaths (SR) Scotland 1903) and general merchant (Deaths (SR) Scotland 1926). The 1861 census lists him as a pig dealer in Brora (Census 1861). There may also be unintentional error in naming parents of a deceased individual-particularly when this individual was very old or the parents were long dead. Fortunately, these issues may be overcome by wider, complementary research including searches for earlier, more contemporary references to an individual's occupation, and also reference to records for collaterals. 
Before 1855, finding the desired information is more challenging even when a known individual can be reliably matched to a surviving birth record. Censuses are a natural resource for occupational references-where an individual survived until 1841 this is helpful. Following an individual forward to the 1851 census - provided a secure match can be made - may produce additional useful data. For the Pittenweem HUGHESes, with their often-duplicated first names, the wife's name in 1841 was used as an identifier and (where this was also duplicated) names and ages of children in the households were also used.

Reference to occupation in parish records is locally variable. Some records meticulously detailed parentage of bride and groom at marriage, and gave occupations for most named adults. Others were less informative and for long periods simply recorded names. Pittenweem falls into this category: often occupations were not given, or only those of "higher-status" bridegrooms (or fathers at baptisms) were specified. Detail within the registers varies, so a man might have an occupation recorded at the baptism of one child but not at others. Sometimes one can work around these limitations within the parish records-for example by researching collaterals.

Pittenweem being a coastal parish, with some shipping in addition to its fishers, fathers often missed baptisms. This was recorded in the parish registers, and a father who was "at sea" can be classified as of maritime occupation even if it is uncertain whether he was a fisher or a mariner at that date. In a father's absence a "sponsor" would present the baby for baptism, and might have his occupation recorded alongside a useful note that he was the child's grandfather or uncle.

More indirect approaches may also bring results. Strategies for using baptismal witnesses as evidence are described below.

1. At Pittenweem baptisms, occupations were sometimes given for witnesses even if not for the father. Extensive reading of registers may produce an occupational record for a witness who elsewhere appears in a vital record of his own without any such details. However, witnesses are not indexed anywhere and so there are no computer short-cuts to accessing such information. It is also necessary to do some wider index searches and some simple population reconstitution to ensure that the researcher is not conflating two local individuals with the same name, particularly as it is possible that occasional occupational identifiers were deliberately given for witnesses whose names were known to be duplicated locally.

2. Sometimes no vital record gives occupational information for a named individual even as a witness elsewhere. Here occupations of the witnesses to a vital event (for that named individual) whether recorded there or established through supplementary sources, become of interest. Witnesses at a baptism were usually relatives or fellow-workers-people connected to the parents either socially or economically. It would be unusual for a non-relative of lesser social status to act as a witness or sponsor. When one is searching for records for fishermen, who were for long periods considered to have low social status (at least in some areas and to those other than themselves), this can provide some circumstantial evidence. Where witnesses were fishers, their appearance at a baptism indicates that the father may be a fisher also, or at least has strong social connections to the fisher-community.

Where vital records were insufficient, the search for occupational references continued in a wide range of other sources. Named Pittenweem fishers are particularly hard to find before 1800: they rarely owned property, did not leave wills and were not recorded as fishers in monumental inscriptions, although some few references occur in documents such as the Burgh records and Pittenweem Sea Box Society records. Where an occupational reference is found for a name of interest, one must ensure that this can be shown to refer to the particular "target individual" rather than someone else of the same name (and perhaps also similar age). Conflation of multiple individuals is a real danger in all forms of historical and genealogical research, and one which is not always adequately considered. Even where a surname is generally uncommon, it may have local prominence or at least some duplication resulting from individuals named according to traditional naming patterns i.e., multiple individuals 
named after a shared ancestor. This was a particular issue in Pittenweem, where the Scottish traditional naming patterns were strong. Again there are strategies which can be used to overcome the issue, including running an elimination process by collecting any candidates of the same name and testing to see whether they can be identified as the "target individual"—or confirmed as someone else. This process should be automatic in any attempt to identify individuals who have no records post 1854, and was conducted in all the cases listed here.

It was also necessary to consider the historical development of the surname "HUGHES" in Pittenweem. The various family groups "normalized" their surname to HUGHES by the late 19th/early 20th century, but the most usual 19th century forms were HEUGH and HEUGHS while in the 18th century the surname usually appears as some spelling variant of HUGH—e.g., HUGH, HEW, HUE, HEUGH—with an occasional terminal "S". Over 20 different spellings were recorded over the period, not all of which were readily picked up by search engine options. Spelling remained very fluid into the later 19th century, and it is not possible to establish a "correct" form at any date or for any individual. This paper has tried to show awareness of the variations in spelling over the period, while each reference to an individual record repeats the exact spelling used there to facilitate access to the original sources.

The issue of common versus uncommon or locally common surnames also came into play in this particular piece of research. One should never assume that all individuals of the same surname, in the same parish, are close blood relatives and, especially prior to 1855 , it is wise to carry out contextual checks on the local representation of any given surname of interest. The surname HUGHES is very familiar in the United Kingdom, where it is usually seen as of Welsh origin. In 1881 the surname was 21st most frequent in the United Kingdom as a whole (British Surnames 2017). However, as late as the Scottish census of 1901, HUGHES still came only 145th in surname frequency (Bowie and Jackson 2003). In Scotland before 1841, the surname was still more unusual. There are very small numbers of vital records for HUGHES/HEUGH variants throughout Fife and the wider eastern Scottish coast-apart from in Pittenweem and a small group in Wemyss, Fife, which seems connected to the coal industry. HUGHES/HEUGH variant records relevant to any identification before 1780 are therefore few.

The tradition under investigation said that the family had fished, i.e., had been fishers, for hundreds of years. A man whose occupation is recorded as "fisher", even once, has been accepted as such, unless an attribution is for some reason dubious (for example unsupported father's details listed on a death certificate-additional sources were always desirable to provide supporting documentation). But where an individual is reliably recorded as having fished, his established fisher status is not cancelled if he is recorded with another occupation at other times. The hunt for alternative sources of occupational information often produced multiple, differing records and revealed that many Pittenweem fishers did have other occupations, either seasonally or at different periods. This presents an opportunity to build more detailed careers for "fisher" individuals, thus clarifying how far they were, or were not, a completely separate and distinct class (Fitzpatrick 2010, p. 36), or even "caste" as some earlier writers have suggested (Nadel-Klein 2003, p. 41; Nadel-Klein 1988, p. 5). Merchant Navy records, especially the BT113 series from 1845-1854, are particularly valuable here (FindMyPast n.d.).

\section{Results}

The fisher's son who passed this tradition on to his descendants was Mitchell HUGHES, born Pittenweem on 13 April 1905 (Births (SR) Scotland (1905)) to Robert Black HUGHES and Janet BUTTERS (m. Dundee 1890; (Marriages (SR) Scotland (1890)), Groom and both fathers are fishermen). Mitchell was the 7th of 10 surviving children recorded in the 1911 census ( 2 others had died).The household occupied 3 rooms at Mid Shore, Pittenweem (Census 1841), and both Robert Black HUGHES and the eldest son present-Joseph, 17-were fishermen. Several other sons later fished for at least part of their lives.

Robert Black HUGHES is also recorded as a fisherman at his marriage to Janet BUTTERS in 1890 (Marriages (SR) Scotland (1890), Both fathers are fishermen); in the 1891 (Census 1891) and 1901 
(Census 1901) censuses; and in his children's birth records (Births (SR) Scotland (1893); Births (SR) Scotland (1899)). He was co-owner of an early steam-trawler in Pittenweem (Eunson 1999, p. 22) from its arrival in 1907 (Reid 2016, p. 113), ${ }^{1}$ and was still actively fishing at his death in 1930 (Deaths (SR) Scotland (1930)). He was certainly a life-long fisher, while son Mitchell, b.1905, began his maritime career around age 9, working on the family steam-trawler "Restless Wave" during his school holidays. ${ }^{2}$

The marriage and death certificates for Robert Black HUGHES both name his parents as George HUGHES fisherman, and Betsy BLACK. A birth record in 1870, matching these parent names and Robert's calculated birth-date, records the father George HEUGHS as a fisherman and the mother as Elizabeth Norrie BLACK (Births (SR) Scotland $\left.(1870)^{3}\right)$, (m. St Andrews 1867, (Marriages (SRP) Scotland (1867), 22 year old George was a fisherman and Elizabeth a domestic servant. Father Mitchell HEUGHES is also a fisherman). This George HEUGHS (elsewhere HEUGHES, HUGHES) appears as a fisherman in the censuses of 1871 (Census 1871) and 1881 (Census 1881), demonstrating another well-documented fisher career.

George HEUGH (later married Betsy or Elizabeth BLACK) was born in 1845 to Mitchell HEUGH fisherman and Mary (previously ANDERSON) (Births and Baptisms (OPR) Scotland (1845)). This couple were married in Pittenweem 1845 (Marriages (OPR) Scotland (1845)), although no occupation was given at marriage there are other fisher references for Mitchell (Births and Baptisms (OPR) Scotland (1854)). The combination of census records and merchant navy records is a powerful tool aiding understanding of how Pittenweem fishers of this period sometimes held other maritime roles. Mitchell HEUGHS (m. Mary ANDERSON 1845, Marriages (OPR) Scotland (1845)), was born to George HEUGH and Margaret OLIPHANT in 1823 (Births and Baptisms (OPR) Scotland (1823)). His first sea-going role was as a mariner, in 1839 (Merchant Navy records. Britain 1845-1854), although he was a fisher in the 1841 census (Census 1841a).

These first generations of male ancestors can be represented as shown below (Table 1)

Table 1. First five generations.

\begin{tabular}{lll}
\hline Generation & Individual & Marriage Details \\
\hline Generation 1 & Mitchell HUGHES b. 1905 & \\
Generation 2 & Robert Black HUGHES b.1870 & m. Janet BUTTERS 1890 \\
Generation 3 & George HEUGH b. 1845 & m. Elizabeth Norrie BLACK 1867 \\
Generation 4 & Mitchell HEUGH b. 1823 & m. Mary ANDERSON 1845 \\
Generation 5 & George HEUGH b. 1794 & m. Margaret OLIPHANT 1823 \\
\hline
\end{tabular}

This 1841 census was of particular interest and value where the Pittenweem fishermen were concerned. 25 of the 75 fishers recorded there $-1 / 3$ of the total-had HUGHES variant surnames. This large overall number and high proportion indicate a strong earlier involvement in fishing by the Pittenweem HUGHES family (or families). The 25 HUGHES variant fishers lived in 16 households, with 9 younger fishermen living in households headed by another HUGHES (Swanson 2013, Appendix F., p. 72). These household heads were shown, through reconstitution of family groups, to be the father or grandfather of the younger men in all but one case (Swanson 2013, Appendix G., p. 77). The 16 fisher households also contained 11 young women or girls listed as netmakers (and none with any other named occupation), indicating that fishing was a real family enterprise there.

This census also showed five HUGHES variant households without a fisher. Widow Elizabeth HEUGH, "85" (Census 1841b), had been married to Robert HUGH/HEUGH (Deaths and Burials (OPR) Scotland 1844) who died a fisher in 1830: his will mentioned boats and gear (Wills and Testaments.

Restless Wave. KY149. Registered 1907, owners Robert HUGHES and G. HUGHES.

HUGHES, Mitchell (pre 1960) oral communication. Mitchell was later Royal Navy, Merchant Navy, engineer on land.

marriage date mistakenly recorded as 20 September 1868. 
Scotland 1831). Christian HEUGH, "30", (no male present) was a net-maker (Census 1841c). Naval pensioner Thomas HEUGH, "65" (Census 1841d), was elsewhere referred to as a coastguard (Census 1851), but was fishing aboard the Walton in 1835 (Merchant Navy Records 1835-1840a). Andrew HUGHES, "65", of Kiln Heugh was another former coastguard (Census 1841e), but again was fishing aboard the Walton in 1835 (Merchant Navy Records. Britain 1835-1840c). Andrew's household included Robert HUGHES, "23", ship's carpenter. One other Pittenweem HUGHES variant male was not listed as a fisher in the 1841 census. Robert HEUGH, age " 30 ", of East Shore, was listed as a merchant seaman, born Fife, wife Margrat aged 28 (Census 1841f). Records show a matching Robert HUGHES fishing aboard the Sovereign in 1836 (Merchant Navy Records 1835-1840a). Family reconstitution shows his father Robert HUGHS " 55 " and younger brother John " 15 " can be found as fishers in 1841, living with 2 netmakers (Census 1841g).

The 1841 census showed a maritime connection in all five of these households. Reconstructing individual careers through other sources revealed that the men also had fisher experience, indicating mobility between fishing and other maritime roles. Including women and children, the HUGHES variant households containing an active fisher in 1841 total 84 individuals: another 14 people lived in HUGHES variant households with no resident fisher then recorded but with demonstrable fisher connections. The local census total was under 1400 , so $6 \%$ of the local population were in H(E)UGH(E)S fisher households, while those in HUGHES variant maritime households of any kind numbered around $1 / 14$ of the whole local population.

Mitchell (Michael) HEUGH b.1823 (Births and Baptisms (OPR) Scotland 1823), the direct male line great-grandfather of Mitchell HUGHES b.1905, appears in the 1841 census as an 18 year old fisher in the household of his father George HEUGH, a Fife-born fisher aged " 45 ", so born about 1791-1795. OPR records show only one George HEUGH (or variant) born in Fife at this period, to James HEUGH and Kethrine DOIG (Births and Baptisms (OPR) Scotland 1794). A matching George HEUGHS died in 1841 (Deaths and Burials (OPR) Scotland 1841), too early for a statutory death certificate which could corroborate his parentage, but the connection indicated by the combination of age at death with census and baptism records available for a George HEUGH (or variant) in Fife is additionally supported by the naming of his eldest son with the locally uncommon first name Mitchell. Katherine DOIG's father was Mitchell DOIG (Marriages (OPR) Scotland 17904). A Mitchell HEUGH for whom there is no O.P.R. baptismal match, but who married in Pittenweem in 1816 (Marriages (OPR) Scotland 1816), had a first son James there in 1817 (Births and Baptisms (OPR) Scotland 1817a), died in Dundee harbour in 1818 and was returned to Pittenweem for burial (Deaths and burials (OPR) Scotland 1818) is arguably the eldest son of Katherine DOIG and her husband James HEUGH. ${ }^{5}$ Other connections between George HEUGH b. 1794 and this early Mitchell, b. abt 1792, are mentioned below. A few Pittenweem individuals, born c.1790-1794, are not recorded in parish baptismal records. There is no visible sign of a page missing or damaged in the digital versions of the surviving parish register, and the absence of these individuals may be due either to Non-Conformist parents or to resistance to the tax on baptismal register entries ((Basten 2010), Stamp Duty Tax, 1783-1794).

George HEUGH or HUGHES and Margaret OLIPHANT, the parents of Mitchell HEUGH b. 1823, married in 1817. George was a mariner (Marriages (OPR)Scotland 1817a, 1817b), so is another HUGHES variant who went to sea in multiple capacities. George was fishing in 1835-1836 (Merchant Navy Records. Britain 1835-1840b) and in 1841. A son's death certificate recorded George as a seaman (Deaths (SR) Scotland 1892)—if this had been accepted without further research, significant

4 Katharin's father named as Mitchel DOEG of Kilrenny.

5 Four year gap between birth of Barbara HEUGH (1790) and George HEUGH (1794). Catherine DOIG's father was Mitchell DOIG. Mitchell HEUGH named first son James, so father should be Mitchell. George HEUGH b. 1794 named first son Mitchell. Mitchell HEUGH and George HEUGH both witnessed baptisms for offspring of sons of James HEUGH and Agnes MUIR. 
details of George's long and varied sea-going career would have been missed. This shows the value of consulting multiple sources when searching for an individual's occupational data.

As Robert Black HUGHES (father of Mitchell HUGHES b.1905 Pittenweem) was still fishing at his death in 1930, the 1841 census showing two generations of direct male line ancestors recorded as fishers (George HEUGH "45", Mitchell HEUGH "18", same household, West Shore, Pittenweem (Census 1841a)) extends the line almost a century to the fourth generation of fisher-ancestry for Mitchell HUGHES b.1905. Additional records show George HEUGH of Pittenweem, "41", fishing in 1835 (Merchant Navy Records. Britain 1835-1840b). But the specific family tradition was that they had fished from Pittenweem for "hundreds" of years-so data is needed at least back to 1730 if the tradition is to be fully assessed.

O.P.R. baptisms offer few competing candidates for James HUGH/HEUGH, husband of Katherine DOIG and father of George b. 1794: these are shown below in Table 2.

Table 2. Candidates for Katherine DOIG's husband.

\begin{tabular}{ccc}
\hline Individual & Birth Year & Parents \\
\hline James HEW & 1729 & James HEW and Margaret PAXTON (Baptisms (OPR) Scotland 1729) \\
\hline James HEUGH & 1758 & James HEUGH and Christian OLIPHANT (Baptisms (OPR) Scotland 1758) \\
\hline James HEUGH & 1769 & Thomas HEUGH and Euphan MUIR (Baptisms (OPR) Scotland 1769) \\
\hline
\end{tabular}

There are no more than two HUGHES variant couples reproducing in Pittenweem at any time up to the late 1770s, and only eight in total between 1721 and 1776. Parish boundaries are permeable, but the baptismal witnesses at HUGHES variant births in Pittenweem show strong interconnections between the small number of individual family groups recorded there in the 18th century, as discussed below.

Two late 18th century family groups in Pittenweem were headed by a James HEUGH: James HEUGH and Agnes MUIR had four sons 1782-1789, while James HEUGH and Katherine DOIG's family-including George b.1794-ran 1790-1801. Agnes MUIR died in 1789, and the sequential dates raise the possibility that one man fathered both families. Additional information of potential value was as follows: Agnes' husband should have been born before 1767 and Katherine's before 1775, while baptismal witness names show that the father of each family was closely connected to other Pittenweem HEUGH men.

Two males named James HEUGH (or variant surname) were born in Pittenweem 1731-1775: to Andrew HEUGH and Christian OLIPHANT, 1758 (Births and Baptisms (OPR) Scotland 1758), and to Thomas HUGH and Euphan MUIR, 1769 (Births and Baptisms (OPR) Scotland 1769). James HEUGH (married Agnes MUIR) can be identified as the son of Andrew HEUGH and Christian OLIPHANT, b.1758. A male born in 1769 is too young to marry by 1782, when James HEUGH and Agnes MUIR had their first son, Andrew (Births and Baptisms (OPR) Scotland 1782a). As an Andrew HEUGH witnessed at the births of two out of four children to James HEUGH and Agnes MUIR (Births and Baptisms (OPR) Scotland 1789; Births and Baptisms (OPR) Scotland 1782b) and acted as sponsor to a third one as the father was at sea (Births and Baptisms (OPR) Scotland 1784), it seems reasonable to conclude that the first son was named for his paternal grandfather and to allocate Andrew HEUGH and Christian OLIPHANT as this James's parents (Births and Baptisms (OPR) Scotland 1758). A James HEUGH and a Thomas HEUGH also witnessed one baptism each to a child of James HEUGH and Agnes MUIR (Births and Baptisms (OPR) Scotland 1786; Births and Baptisms (OPR) Scotland 1784), indicating several links running from this James HEUGH to other Pittenweem HEUGH variant men. The couple's four sons had first names already used by Pittenweem HEUGH variant families-Andrew, James, Thomas and William. At Agnes MUIR's death in 1789, husband James was recorded as a fisher (Deaths and Burials (OPR) Scotland 1789). 
Should James HEUGH, who married Katherine DOIG at South Leith in 1790 and had five children ${ }^{6}$ baptised in Pittenweem 1790-1801, then be identified as the son of Thomas HEUGH and Euphan MUIR, (b.1769)? Although this may superficially seem an attractive conclusion, there are several reasons why it is a poor fit.

Firstly, there is another marriage recorded to a James HEUGH in Pittenweem-James HEUGH and Helen OVENSTON married in 1792 (Marriages (OPR) Scotland 1792). Helen OVENSTON's husband clearly cannot be the same man as Katherine DOIG's husband as Katherine, married in 1790, produced children in Pittenweem 1790-1801. Therefore there are still two James HEUGH individuals present in the parish in 1792, either of whom might be Agnes MUIR's widower or Thomas HEUGH's son (or someone different).

Secondly, Katherine DOIG, who married James HEUGH, "sailor", in South Leith in January 1790, was then recorded as "daughter of the deceased Mitchell DOEG, millar in the parish of Kilrenny" (Marriages (OPR) Scotland 17907). Mitchell DOIG and Barbara BOWMAN's daughter Katherine was baptised in 1759 (Births and Baptisms (OPR) Scotland 1759a ${ }^{8}$ ). She would be rather old to marry someone b.1769, but a good age match for someone b.1758. Thomas and Euphan's son would only have been 20 in January 1790, while Katharine DOIG was then turning 32.

Thirdly, and more conclusively, the names of James HEUGH and Katherine DOIG's children (tabulated below) are atypical for HEUGH families in the parish of Pittenweem. This could be explained if this family runs on from that of James HEUGH and Agnes MUIR. The first daughter is named after the maternal grandmother (Barbara), but the first son (if Mitchell HEUGH is this couple's child) is named for the maternal grandfather. George and Alexander, also previously unknown in the 18th century HEUGHs families of Pittenweem, are the names of Katherine's maternal and paternal grandfathers. John was previously used in Pittenweem HEUGH variant families-a John was born to James HUGH and Marjory WOOD in 1733 and, if we accept the likelihood that James husband of Katharine DOIG had previously been married to Agnes MUIR, John would be the name of a great-uncle. There is no overlap in names between these two family groups-most unusually for Pittenweem HEUGH variant families-until one reaches James b. 1801. Normally the paternal grandfather's name would come first (and there is no Thomas in this group) and the father's name would come 3rd in a sequence of boys, rather than 5th - the late appearance of the name James in 1801 may reflect the loss of James b.1784 to James HEUGH and Agnes MUIR. If Katherine DOIG's husband was James son of Thomas and Euphan, he had ignored not only his father's name but those of his brothers (Thomas (Births and Baptisms (OPR) Scotland 1773) and Andrew (Births and Baptisms (OPR) Scotland 1774)) in favour of names primarily from the maternal line.

The data on the two family groups is tabulated below (Table 3).

\footnotetext{
We have postulated a sixth child, Mitchell HEUGH b. 1791-1793.

James is "sailor in Leith".

Parents Mitchel DOEG and Barbara BOWMAN.
} 
Table 3. Events for families headed by a James HUGH variant.

\begin{tabular}{|c|c|c|}
\hline Couple & Events & Additional Data \\
\hline $\begin{array}{l}\text { James HUGH/HEUGH and Agnes MUIR } \\
\text { James matches James HEUGH b. to Andrew } \\
\text { HEUGH and Christian OLIPHANT in } 1758 .\end{array}$ & $\begin{array}{c}\text { Married } 1790 \\
\text { Andrew b. } 1782 \\
\text { James b. } 1784 \\
\text { Thomas b. } 1786 \\
\text { William b. } 1789 \\
\text { Agnes died } 1789\end{array}$ & $\begin{array}{l}\text { All four first names used in earlier } \\
\text { HUGHES variant records in Pittenweem. } \\
\text { Andrew for both grandfathers. } \\
\text { James for father. } \\
\text { Thomas and William the names of } \\
\text { father's brothers. }\end{array}$ \\
\hline $\begin{array}{c}\text { James HUGH/HEUGH and Katherine } \\
\text { DOIG (various spellings) }\end{array}$ & $\begin{array}{c}\text { Married January } 1792 \\
\text { Barbara b. } 1790 \\
\text { (Mitchell) b. abt } 1792 \\
\text { George b. } 1794 \\
\text { John b.1796 } \\
\text { Alexander b.1798 } \\
\text { James b. } 1801\end{array}$ & $\begin{array}{l}\text { Katherine's mother Barbara. } \\
\text { Her father Mitchell. } \\
\text { Her grandfathers George and Alexander. }\end{array}$ \\
\hline $\begin{array}{c}\text { NB James son of Thomas and Euphan had } \\
\text { brothers Thomas and Andrew }\end{array}$ & & \\
\hline
\end{tabular}

One might argue that the two groups of names indicate that a "new" James HEUGH had arrived in the parish, adducing as evidence that at Katharine DOEG's marriage her husband was "sailor in the parish of Leith". But contemporary evidence states that many Pittenweem men migrated to other ports to work as mariners (The Statistical Account of Scotland 1791-1799), and it is unclear why a mariner from South Leith (or indeed elsewhere) would wish promptly to settle in Pittenweem to fish, at a time when fishing was proving unrewarding (The Statistical Account of Scotland 1799) and when his wife came from Kilrenny. This paper shows that many Pittenweem fishers did indeed serve as mariners either at some periods of their lives or seasonally. Also it is well understood that a man without a woman in his household could not function as a fisherman in the 18th century-strong domestic support was required to manage an irregularly-timetabled household and to bait hooks for line-fishing or to make and care for herring-nets (Coull 1996, p. 50).

Four James HEUGH variants were born elsewhere in Fife in a plausible time-frame, but three had fathers whose names do not appear among James and Katherine's five sons (Adam (Births and Baptisms (OPR) Scotland 1767a) and Archibald (Births and Baptisms (OPR) Scotland 1767b)-both uncommon - and William (Births and Baptisms (OPR) Scotland 1771a) while James HEWCH of Tulliallan, whose father was named Michael (Births and Baptisms (OPR) Scotland 1770), appears to have died in childhood (Deaths and Burials (OPR) Scotland 1774) ${ }^{9}$.

Finally—and I would argue conclusively—the "two families" of James HEUGH and Agnes MUIR, and James HEUGH and Katharine DOIG (which are closely consecutive) are shown, through the names of baptismal witnesses, to be closely interlinked. Generally, HUGHES variant men only appear as baptismal witnesses to other HUGHES variants-in the few instances between 1700 and 1855 where this was not so, one of the baby's parents was normally a HUGHES relative by marriage (Births and Baptisms (OPR) Scotland 1817b). An Andrew HEUGH (on three occasions), Thomas HEUGH and James HEUGH witnessed baptisms of James HEUGH's children with Agnes MUIR, as did a John WATT (Births and Baptisms (OPR) Scotland 1789), probably the fisher who married Marjory, daughter of Andrew HEUGH and Christian OLIPHANT (Marriages (OPR) Scotland 1787).

The group of baptismal witnesses for children of James HEUGH and Katharine DOIG shows a strong similarity to that for the earlier family. Four of five among these baptisms were witnessed by Andrew HEUGH and by either John WATT or James WATT: a James WATT married Margaret HEUGH, again probably daughter to Andrew HEUGH and Christian OLIPHANT (Marriages (OPR) Scotland 1789).

9 NB. On Scotland's People website, surname mistakenly transcribed as HEOGH. 
The James WATT and John WATT who married HEUGH daughters were both fishers (Deaths and Burials (OPR) Scotland 1774 ${ }^{10}$; Deaths and Burials (OPR) Scotland 1842) ${ }^{11}$.

Pursuing this research strategy through a second generation, it can be seen that men from the "first family" appear to have witnessed for baptisms to children of men from the "second family" and vice versa. Early 19th century Pittenweem records show multiple HEUGH individuals named James, Andrew, Thomas or William. These names among witnesses might then only indicate that the sons of the two couples were part of some wider HUGHES variant family in Pittenweem, although this would strongly counter any suggestion that James HEUGH, husband of Katherine DOIG, was a newcomer to the parish. But Mitchell HEUGH witnessed at the baptism of James (parents William HEUGH and Agnes CUNNINGHAM) in 1812 (Births and Baptisms (OPR) Scotland 1812). Similarly, George HEUGH made a rare witness appearance at the baptism of Agnes (daughter of William HEUGH and Agnes CUNNINGHAM) in 1817 (Births and Baptisms (OPR) Scotland 1817c). This William HEUGH was the youngest son in the earlier family under discussion, while Mitchell and George were the eldest two sons of the later family.

For the children of the later family there is usually at least one HUGHES variant witness-often Andrew HEUGH and/or Thomas HEUGH, names from the first family rather than the second.

In summary, the sequential dates of the two family groups in Pittenweem between 1780 and 1801, with a father named James HEUGH (or variant), and the lack of overlap between children's names in the two family groups, indicate that the two families might have one father. The parentage of Agnes MUIR's husband was clear, and the names of the children in the second family failed to reflect known family names for alternative candidates for the James who married Katherine DOIG. The two family groups showed a strong overlap in the names of baptismal witnesses, and in due course sons from the first family acted as baptismal witnesses for children to sons of the second family-and vice versa. Overall it seems a logical and firm conclusion that the "two families" are in fact one, where a single James HEUGH (son of Andrew HEUGH and Christian OLIPHANT) took two consecutive wives.

Evidence from collaterals can be of great value in this period, where a later 18th century individual may die before statutory death records appear. Statutory death evidence from George HEUGH's younger brothers records their father James as another Pittenweem fisher in the direct line (Deaths (SR) Scotland 1860). Combining occupational data for the male in both couples under discussion indicates that James HEUGH, husband first of Agnes MUIR and later (it is here argued) of Katherine DOIG, was a long-time fisher who served at least one period as a mariner. Identifying James HEUGH (married Katharine DOIG) as the former husband of Agnes MUIR means that an earlier fisher record (Deaths and Burials (OPR) Scotland 1789) can be added to the occupational record of the father of George HEUGH b.1794, and direct line fisher records can be rolled back to 1789. There are however many records that George's father, husband of Katherine DOIG, fished-and so the issue of fisher ancestry in this direct male line is not in question whether or not this James had earlier married Agnes MUIR.

Did the previous generation also fish? Andrew HUGH and Christian OLIPHANT, who married in 1754 (Marriages (OPR) Scotland 1754), produced their family in Pittenweem at an interesting stage of the wider HEUGH family's development. Four HEUGH variant couples produced children in the 21 years between 1755 and 1776, as shown below (Table 4).

10 Spouse of James WATT, Senr, fisherman. Age 73.

11 "Wife of John WATT fisher". 
Table 4. HUGHES variant families reproducing Pittenweem 1755-1776.

\begin{tabular}{cccc}
\hline Family 1 & Family 2 & Family 3 & Family 4 \\
\hline $\begin{array}{c}\text { Andrew HUGH and Christian } \\
\text { OLIPHANT, m. 1754. }\end{array}$ & $\begin{array}{c}\text { William HUGH and } \\
\text { Margaret CHAPMAN, } \\
\text { married 1754 }\end{array}$ & $\begin{array}{c}\text { James HUGH and Isabell } \\
\text { HALL, m. 1758 }\end{array}$ & $\begin{array}{c}\text { Thomas HUGH m. Euphan } \\
\text { MUIR, m. 1768. }\end{array}$ \\
\hline 1755 Marjory & & & \\
1758 James & & & 1769 James \\
1764 Andrew & 1759 Robert & 1760 Isabell & 1773 Thomas \\
1766 Thomas & 1764 Janet & & 1774 Andrew \\
1769 Margaret & & & 1776 "a woman child named John" \\
1772 William & & \\
1773 Christian & & & \\
\hline
\end{tabular}

James HUGH "Snr", James HUGH "Jnr" and Thomas HUGH all appear as baptismal witnesses for the children of Andrew HUGH and Christian OLIPHANT. The naming pattern in the family group suggests that Andrew is the son of James HEW/HUGH and Marjory WOOD (Births and Baptisms (OPR) Scotland 1731), and this is supported by the appearance of James HEUGH Snr among the witnesses. The only Thomas HEUGH variant recorded in the Pittenweem OPR before 1750 is Thomas b. to James HEW /HUGH and Marjory WOOD in 1744, so this witness name for one of Andrew and Christian's children probably refers to the child's uncle.

Andrew HUGH, husband of Christian OLIPHANT, had married a fisher's daughter (Births and Baptisms (OPR) Scotland 1734; Dobson 2008). Thomas HUGH, Andrew's brother who witnessed at two children's baptisms (1769 and 1772) is elsewhere recorded in just that period as a fisher in Pittenweem (Births and Baptisms (OPR) Scotland 1768). The witnesses to the 1766 baptism of Thomas HUGH, third son to Andrew and Christian, were Robert DAVIDSON and William MELVILLE, then described in the register as fishers in the parish (Births and Baptisms (OPR) Scotland 1766). Clearly Andrew is part of the Pittenweem fisher community at this period. Andrew HUGH himself was "at sea" in 1755, when his first child Marjory was baptized (Births and Baptisms (OPR) Scotland 1755), although as yet there is no direct reference found in records of him being a fisher. This does not mean that he did not fish — the activity often went unrecorded: indeed it seems unlikely, given his level of social involvement with the fishers of the parish, that he should not have had any fisher experience himself. Moreover, at least two of Andrew's sons fished-James b. 1758 (Births and Baptisms (OPR) Scotland 1758; Deaths and Burials (OPR) Scotland 1789) and William b. 1772 (Births and Baptisms (OPR) Scotland 1771b; Deaths and Burials (OPR) Scotland 1802)—and daughters Marjory and Margaret married two fishermen (Marriages (OPR) Scotland 1787; Marriages (OPR) Scotland 1789). With a fisher father, father-in-law, brother, sons and sons-in-law, definite absence at sea on at least one occasion plus known fisher witnesses at his children's baptisms, it seems reasonable to classify this Andrew HUGH as a fisher for at least part of his lifetime.

What about Andrew HUGH's father? It was earlier shown that this generation of the Pittenweem HUGHES variant family has at least one fisher representative in this Andrew's brother Thomas, the husband of Euphan MUIR. A corollary of this is that, should James (m. Katherine DOIG) prove to be the son of Thomas (m. Euphan MUIR) rather than of Andrew (m. Christian OLIPHANT), the evidence for a fisher father for James (m. Katherine) becomes direct rather than circumstantial but strong. And as Andrew HEUGH (m. Christian OLIPHANT) and Thomas HEUGH (m. Euphan MUIR) have been shown to be brothers, the next generation back will take us to the same individual if either option is correct.

As one moves back in time, the number of HUGHES variant family groups in Pittenweem becomes smaller, and the number of recorded candidates for any individual is correspondingly reduced. However, records of baptismal witnesses continue to indicate links between the few family groups in the parish. Between 1720 and 1750 there are HUGHES variant men of two names-James and William-producing children in the parish. In each case there are two consecutive families and one could conduct a case study, along similar lines to that for James HEUGH and Agnes MUIR/James 
HEUGH and Katherine DOIG, in order to address the question of whether these four family groups represent the children of two men or of four. However, this is tangential to the main question under discussion here and will be tackled elsewhere.

Only one Andrew HEUGH/HUGH birth is recorded in the four groups-Andrew HEW son of James HEW and Marjory WOOD (Births and Baptisms (OPR) Scotland 1731). As Christian OLIPHANT's father was Andrew and her mother Margaret, while her children with Andrew HEUGH included first two sons James and Andrew, and first two daughters Marjory and Margaret, and "James HEUGH Snr" witnessed a baptism in this family (Births and Baptisms (OPR) Scotland 1764), it seems reasonable to conclude that James HUGH/HEW and Marjory WOOD were the parents of Andrew HEW/HUGH/HEUGH who married Christian OLIPHANT. The fifth to eighth generations can therefore be summarized as shown below (Table 5).

Table 5. Generations 5 to 8.

\begin{tabular}{ccc}
\hline Generation & Individual & Marriage Data \\
\hline Generation 5 & George HEUGH b. 1794 & m. Margaret OLIPHANT 1823 \\
Generation 6 & James HEUGH b. 1758 & m. (2) Katherine DOIG \\
Generation 7 & Andrew HEUGH b. 1731 & m. Christian OLIPHANT 1754 \\
Generation 8 & James HEW b. bef 1711 & m. Marjory WOOD \\
\hline
\end{tabular}

Unexpectedly, there was no difficulty in identifying the occupation for this James-his marriage record from 1729 states that he is "fisher in Pittenweem" (Marriages (OPR) Scotland 1729). It is fortunate that he was married in another parish, as the Pittenweem records at the time were decidedly uninformative. Children of James HUGH and Marjory WOOD are displayed below (Figure 1).

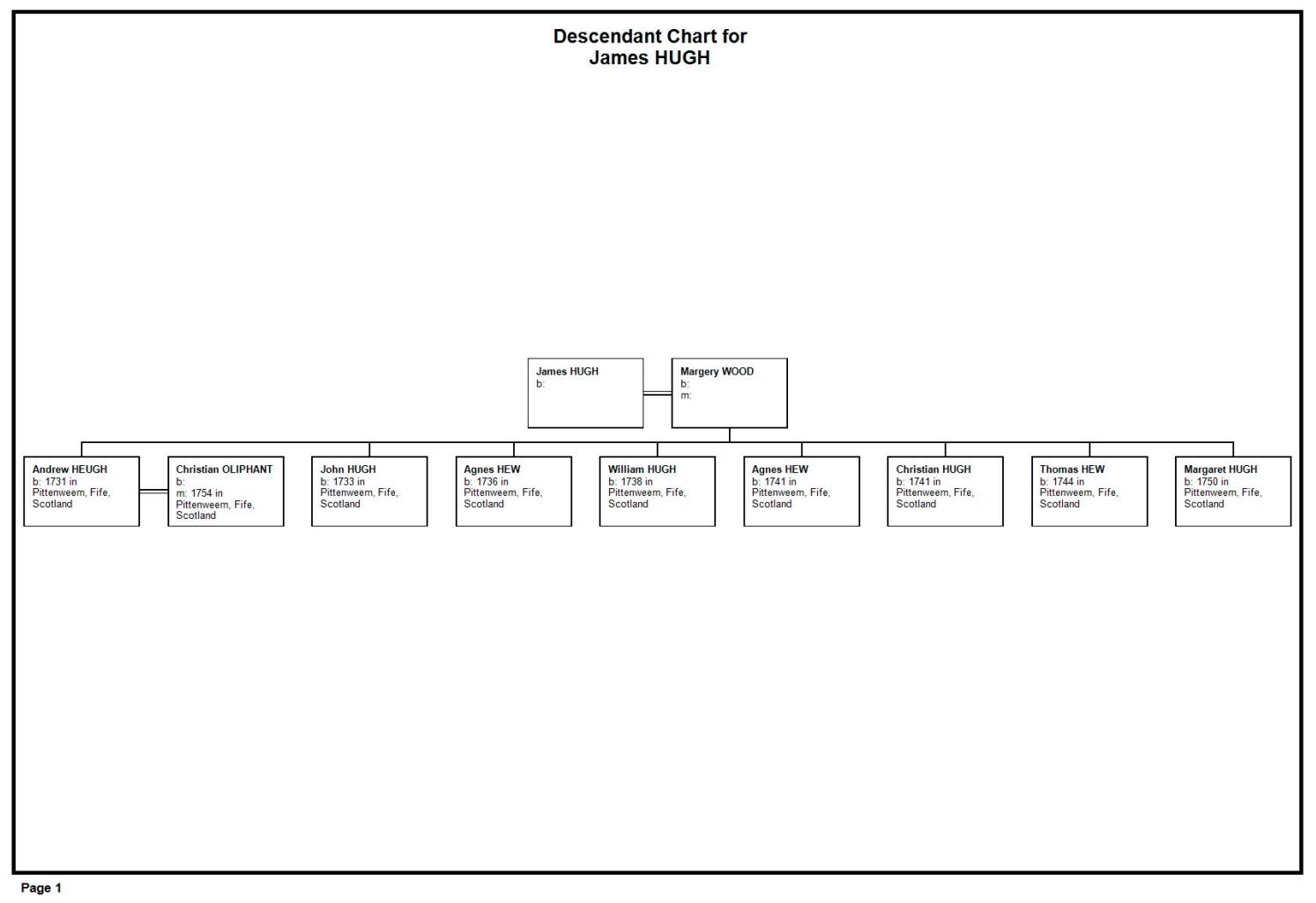

Figure 1. Children of James HUGH and Marjory WOOD. 


\section{Discussion}

With a fisher record from 1729 for a direct male line ancestor, research has now found evidence of fishers in every generation of the male line for just over 200 years from the death of Robert Black HUGHES in 1930. Although the evidence for fishing in the direct male line is only circumstantial in the case of Andrew HEUGH m. Christian OLIPHANT, that circumstantial evidence is strong even if one chooses not to adduce the opinions of various authors who have stated that fishers were a fairly distinct class of low status who inherited their occupation and rarely intermarried-some recent research has indicated that Pittenweem in the late 18th century and early 19th seems to be an exception to this commonly held belief (Swanson 2013, Appendix F., p. 72; Swanson 2014). However, even if we do not accept Andrew HEUGH (married Christian OLIPHANT) as a fisher himself, his brother Thomas HEUGH certainly fished and so this generation of the Hughes variant line definitely maintains the fisher link in that respect. Examination of the family tradition of the "fishing HUGHESes of Pittenweem" has therefore found it to be substantively accurate-the line which included Mitchell HUGHES, b. 1905 to Robert Black HUGHES, did indeed fish in Pittenweem for hundreds of years, back from 1930 to at least 1729.

Did HUGHES variant men fish in Pittenweem before 1729? There is no mention of it in parish registers, but Burgh records contain two relevant 17th century references. A John HEW was one of the men allocated to Alexander WANDERSONE's small-lyne boat in 1663, as part of an attempt to end competition between boat owners for fisher crew (Cook 1867, p. 84). At the Winter Herring Drave of 1695, a John HEW was among fishers summoned for selling fish against the burgh regulations: he admitted selling 10,000 herring for $£ 50$ Scots (Cook 1867).

Here we have two references to a John HEW, fisher, more than 30 years apart. They might both refer to the same man, if he was relatively young in 1663 - or they might be two men of different generations. There are very few 17th century references to HUGHES variants in Pittenweem, and only one to the baptism of a male: John HEWE born to John HEWE in 1649 (Births and Baptisms (OPR) Scotland 1649). The man in the 1663 fisher reference could therefore be either the father or the son from this baptismal record-a young fisher of 14 or an older man of over 30 .

Later, a John HUGH had a son James with Janet BAVERIS or BAVERIDGE in 1699 (Births and Baptisms (OPR) Scotland 1699), and this son could possibly be the individual who married Marjory WOOD in 1729-however the few surviving HUGHES variant birth records for Pittenweem between 1640 and 1705 do not account for all the HUGHES variant men who are recorded as reproducing there from the 1720 s onwards. It would require a whole separate paper to attempt to disentangle and integrate such alternative sources as survive. For the moment one can only say that there are certainly records of some HEUGH variant individuals fishing in Pittenweem as far back as 1663-around 270 years back from our fixed point of the death of Robert Black HUGHES in 1930. Other HUGHES men undoubtedly fished in Pittenweem after 1930, so it should be possible to confirm local fisher records for the surname over at least 300 years altogether.

So the family tradition repeated in the 1950s by Mitchell HUGHES b. 1905-that his HUGHES ancestors had fished in Pittenweem for hundreds of years-does appear to be correct both in its most rigorous form (the direct male line) and also in a more extended form encompassing a wider "family". Establishing the length of time during which this family line fished in Pittenweem partly depends on whether it proves possible to link the HUGHES variant men of the 1720s back to the HUGHES variant families resident in the parish before 1710. This raises the issue of whether the whole small group of HUGHES variant families recorded in Pittenweem before 1800 should be regarded as one larger family or as multiple lines co-incidentally bearing the same relatively uncommon surname and following the same occupation.

Could all these fishing and other maritime HUGHES variant men be part of one extended family? In an earlier study, on occupational inheritance among Pittenweem fishers of the 1841 census (Swanson 2013), the fathers and grandfathers of the 1841 Pittenweem fishers were identified where possible. 23 of the 25 HUGHES variant fishers in 1841 could be firmly identified, with 18 being sons or 
grandsons of only three couples. A further four, in the household of the elderly, active fisher William HUGHS aged "70", were his sons or grandsons. The two men of unconfirmed parentage each lived with a descendant of this William HUGHS. So 22 out of 25 fishers descended from four couples, while the 23rd fisher was a survivor of one of those couples himself and the last two seem connected to that 23rd fisher. These four ancestral couples, tabulated below, are clearly of great interest to the question of wider family membership (Table 6).

Table 6. Ancestral couples for Pittenweem fishers in 1841.

\begin{tabular}{lll}
\hline $\begin{array}{l}\text { COUPLE (in bold if male } \\
\text { deceased by 1841) }\end{array}$ & $\begin{array}{l}\text { Fisher sons in 1841, plus spouse as } \\
\text { identifier if needed. Individuals in } \\
\text { brackets not present as fishers 1841. }\end{array}$ & $\begin{array}{l}\text { Fisher grandsons in 1841 } \\
\text { (father in each case in central column) } \\
\text { Age and wife's name included as identifiers. }\end{array}$ \\
\hline $\begin{array}{l}\text { James HEUGH (fisher by 1789) and } \\
\text { Agnes MUIR }\end{array}$ & $\begin{array}{l}\text { Andrew HEUGHS (58) } \\
\text { Thomas HUGHS (50) } \\
\text { William HUGHS (50) }\end{array}$ & $\begin{array}{l}\text { Andrew HUGHS(20) (Isabella HUGHS) } \\
\text { William HUGHS (20) } \\
\text { (Christian ANDERSON) }\end{array}$ \\
\hline & (Mitchell HEUGH, d.1817) & $\begin{array}{l}\text { James HEUGH (23) } \\
\text { (Elizabeth THOMSON) }\end{array}$ \\
$\begin{array}{ll}\text { James HEUGH (fisher by 1789) and } \\
\text { Katherine DOIG }\end{array}$ & $\begin{array}{l}\text { George HEUGH (45) } \\
\text { George HEUGH (14) }\end{array}$ \\
& Alexander HEUGHS (41) & $\begin{array}{l}\text { James HEUGHS (15) } \\
\text { John HEUGH (15) }\end{array}$ \\
\hline $\begin{array}{l}\text { Robert HEUGH (Navy pre-1785, then } \\
\text { poss. mariner, later fisher) and Betty } \\
\text { HALLIBURTON or BRUNTON }\end{array}$ & $\begin{array}{l}\text { James HEUGH (35) } \\
\text { Robert HUUGH) }\end{array}$ & $\begin{array}{l}\text { Andrew HEUGH (25) } \\
\text { William HUGHS (26) }\end{array}$ \\
\hline $\begin{array}{l}\text { William HUGHS (fisher before 1800) } \\
\text { and Barbara HENDERSON }\end{array}$ & $\begin{array}{l}\text { Andrew HUGHS(30) (Agnes) } \\
\text { James HUGH (25) }\end{array}$ & William HUGHS (11) \\
& (Jane/Jean BELL) & \\
\hline
\end{tabular}

This paper has demonstrated that James HEUGH, husband of Agnes MUIR, is most probably the same man as the James HEUGH who later married Katherine DOIG. James HEUGH, husband of Agnes, is the son of Andrew HEUGH and Christian OLIPHANT, based on name, age, children's names and names of baptismal witnesses, and a clear level of connection to other HUGHES variant men then in the parish. William HEUGH/HUGHS (m. Barbara HENDERSON) is a match for another son of Andrew HEUGH and Christian OLIPHANT. This would make 20 of the 1841 Pittenweem fishers the sons, grandsons or great-grandsons of Andrew HEUGH and Christian OLIPHANT, leaving one son and three grandsons of Robert HEUGH (m. Betty HALLIBURTON or BRUNTON) listed as fishers in the 1841 census. This Robert HEUGH or HUGH, who has a locally very unusual name combination, is a match for the son of William HEUGH and Margaret CHAPMAN, b. 1759 (Births and Baptisms (OPR) Scotland 1759b). A James HUGH witnessed this baptism, and this might be the husband of Marjory WOOD and probable father of Andrew HEUGH (m. Christian OLIPHANT)—although the parish records do give alternative candidates for this James. But there are no clear indications of how William HEUGH (m. Margaret CHAPMAN) might connect to the line of James HUGH (m. Marjory WOOD 1729)—and some indications that any potential intersection of the lines may come before 1700. Sadly the parish baptismal records for 1655-1685 are missing, as are marriage records for 1660-1692-and there are few death or burial records before 1782 (FamilySearch 2017).

Here genetic genealogy may prove of value. Recently contact was made by a HUGHES in North America, whose direct male line had reputedly arrived there in 1756 under the surname HUGH. Y-DNA testing had shown a close match to the line of Mitchell HEUGH b. 1905-to within a few hundred years. It was possible to confirm through primary historical documents this family's tradition regarding the date and manner of their HUGH ancestor's arrival in North America and this, combined with the evidence of the genetic testing, is of value in two ways. 
Firstly it confirms that the family surname-usually spelled HUGH, HEUGH, HEW or HUE in Pittenweem in the 18th century and later independently regularised to HUGHES in both these lines-was of long standing, and that the two lines must connect at a point where the surname was already in use. Secondly it indicates that, at least as far back as the point of intersection (which is not yet fully established but must be before 1712) the direct male line has run true on both sides and so the tests have produced a genuine "HUGHES of Pittenweem" DNA signature. The haplotype is R1a-L664, rare in Scotland (Geni n.d.) and therefore quite distinctive.

The DNA evidence thus raises the possibility of clarifying the degree of connection between the various family lines of HEUGH variant fishers in Pittenweem. There were three HEUGH variant family groups in Pittenweem producing sons in the 1750s and 1760s, and in all three cases either the father, or one or more sons, or both can be shown to have been among the small number of fishers there before 1800. So if any reader can trace a direct male line back to Andrew HEUGH (m. Christian OLIPHANT 1754) or Thomas HEUGH (m. Euphan MUIR by c.1769), possibly brothers; or to William HEUGH (m. Margaret CHAPMAN 1754)—who may be a cousin, or something completely different-Y-DNA test results could help to clarify the relationship between these couples and thus expand understanding of the connections between HUGHES variant fishers of Pittenweem. It would also be useful to have test results for a male line descendant specifically of James HEUGH and Agnes MUIR, to compare with that of the line of James HEUGH who later married Katherine DOIG.

\section{Conclusions}

In conclusion, research showed that the family tradition of Mitchell HUGHES b. 1905 was unusually accurate: the direct male line can be seen fishing for at least eight generations and over 200 years, while there were also records of HUGHES variant fishers in the parish as early as 1663. Investigating the tradition provided considerable understanding of the historic role of HUGHES variant fishers and mariners of Pittenweem, but there is still much to learn about this group with its remarkably strong and long-term sea-going focus.

Conflicts of Interest: The author declares no conflict of interest.

\section{References}

Baptisms (OPR) Scotland. 1729. Pittenweem, Fife. 452. March 16. HEW, James. GROS data 452/00 00100268. Available online: http:/ / www.scotlandspeople.gov.uk (accessed on 20 June 2013).

Baptisms (OPR) Scotland. 1758. Pittenweem, Fife. 452. April 23. HUGH, James. GROS data 452/00 00200023. Available online: http:/ / www.scotlandspeople.gov.uk (accessed on 20 June 2013).

Baptisms (OPR) Scotland. 1769. Pittenweem, Fife. 452. November 5. HEUGH, James. GROS data 452/00 0020 0060. Available online: http:/ / www.scotlandspeople.gov.uk (accessed on 20 June 2013).

Basten, Stuart. 2010. The Impact of the 1783 and 1785 Stamp Duty Acts on Scottish Vital registration. Journal of Scottish Historical Studies 30: 64-74. [CrossRef]

Births (SR) Scotland. 1870. Pittenweem, Fife, 452. August 24. HEUGHS, Robert Black. GROS data 452/00 0040. Available online: http:/ / www.scotlandspeople.gov.uk (accessed on 20 June 2013).

Births (SR) Scotland. 1893. Pittenweem, Fife. 452. August 30. HUGHES, Joseph. GROS data 452/00 0037. Available online: http:/ / www.scotlandspeople.gov.uk (accessed on 20 June 2013).

Births (SR) Scotland. 1899. Peterhead, Aberdeen. 232. July 22. HUGHES, Betsy Black. GROS data 232/01 0307. Available online: http:/ / www.scotlandspeople.gov.uk (accessed on 20 June 2013).

Births (SR) Scotland. 1905. Pittenweem, Fife. 452. April 19. HUGHES, Mitchell. GROS data 452/00 0010. Father Robert HUGHES, fisherman. Available online: http:/ / www.scotlandspeople.gov.uk (accessed on 20 June 2013).

Births and Baptisms (OPR) Scotland. 1649. Pittenweem, Fife. 452. August 12. HEWE, John. GROS data 452/00 0010 0095. Available online: http:/ / www.scotlandspeople.gov.uk (accessed on 20 June 2013).

Births and Baptisms (OPR) Scotland. 1699. Pittenweem, Fife. 452. August 27. HEW, James. GROS data 452/00 0010 0171. Available online: http:/ / www.scotlandspeople.gov.uk (accessed on 20 June 2013). 
Births and Baptisms (OPR) Scotland. 1731. Pittenweem, Fife. 452. September 30. HEW, Andrew. GROS data 452/00 0010 0277. Available online: http:/ / www.scotlandspeople.gov.uk (accessed on 20 June 2013).

Births and Baptisms (OPR) Scotland. 1734. Pittenweem, Fife. 452. April 28. OLIPHANT, Christian. GROS data 452/00 0010 0288. Available online: http:/ / www.scotlandspeople.gov.uk (accessed on 20 June 2013).

Births and Baptisms (OPR) Scotland. 1755. Pittenweem, Fife. 452. October 28. HUGH, Marjory. GROS data 452/00 0020 0018. Available online: http:/ /www.scotlandspeople.gov.uk (accessed on 20 June 2013).

Births and Baptisms (OPR) Scotland. 1758. Pittenweem, Fife. 452. April 23. HUGH, James. GROS data 452/00 00200023 . Available online: http:/ / www.scotlandspeople.gov.uk (accessed on 20 June 2013).

Births and Baptisms (OPR) Scotland. 1759a. Kilrenny, Fife, 438. September 9. DOEG, Katharine. GROS data 438/00 0010 0267. Available online: http:/ / www.scotlandspeople.gov.uk (accessed on 20 June 2013).

Births and Baptisms (OPR) Scotland. 1759b. Pittenweem, Fife. 452. October 19. HUGH, Robert. GROS data 452/00 0020 0025. Available online: http:/ / www.scotlandspeople.gov.uk (accessed on 20 June 2013).

Births and Baptisms (OPR) Scotland. 1764. Pittenweem, Fife. 452. May 27. HEUGH, Andrew. GROS data 452/00 0020 0036. Available online: http:/ / www.scotlandspeople.gov.uk (accessed on 20 June 2013).

Births and Baptisms (OPR) Scotland. 1766. Pittenweem, Fife. 452. March 23. HEUGH, Thomas. GROS data 452/00 0020 0044. Available online: http:/ / www.scotlandspeople.gov.uk (accessed on 20 June 2013).

Births and Baptisms (OPR) Scotland. 1767a. Torryburn, Fife, 458. September 6. HUGH, James. GROS data 458/00 0020 0186. Available online: http:/ / www.scotlandspeople.gov.uk (accessed on 20 June 2013).

Births and Baptisms (OPR) Scotland. 1767b. Wemyss, Fife. 459. May 19. HEUGH, James. GROS data 459/00 0030 0236. Available online: http:/ / www.scotlandspeople.gov.uk (accessed on 20 June 2013).

Births and Baptisms (OPR) Scotland. 1768. Pittenweem, Fife. 452. Born March 10. Baptised 11 March 1768. MUIR, John. GROS data 4520000020 0052. Available online: http:/ / www.scotlandspeople.gov.uk (accessed on 20 June 2013).

Births and Baptisms (OPR) Scotland. 1769. Pittenweem, Fife, 452. November 5. HEUGH, James. GROS data 452/00 0020 0060. Available online: http:/ / www.scotlandspeople.gov.uk (accessed on 20 June 2013).

Births and Baptisms (OPR) Scotland. 1770. Tulliallan, Fife. 397. May 21. HEWGH, James. GROS data 397/00 0010 0232. Available online: http:/ / www.scotlandspeople.gov.uk (accessed on 20 June 2013).

Births and Baptisms (OPR) Scotland. 1771a. Dunfermline, Fife. 424. August 25. HUGH, James. GROS data 424/00 0060 0484. Available online: http:/ / www.scotlandspeople.gov.uk (accessed on 20 June 2013).

Births and Baptisms (OPR) Scotland. 1771b. Pittenweem, Fife. 452. January 24. HEUGH, William. GROS data 452/00 0020 0068. Available online: http:/ / www.scotlandspeople.gov.uk (accessed on 20 June 2013).

Births and Baptisms (OPR) Scotland. 1773. Pittenweem, Fife. 452. February 7. HEUGH, Thomas. GROS data 452/00 0020 0072. Available online: http:/ / www.scotlandspeople.gov.uk (accessed on 20 June 2013).

Births and Baptisms (OPR) Scotland. 1774. Pittenweem, Fife. 452. March 26. HEUGH, Andrew. GROS data 452/00 0020 0077. Available online: http:/ /www.scotlandspeople.gov.uk (accessed on 20 June 2013).

Births and Baptisms (OPR) Scotland. 1782a. Pittenweem, Fife. 452. September 1. HEUGH, Andrew. GROS data 452/00 0020 0124. Available online: http:/ / www.scotlandspeople.gov.uk (accessed on 20 June 2013).

Births and Baptisms (OPR) Scotland. 1782b. Pittenweem, Fife. 452. September 1. HEUGH, Andrew. GROS data 452/00 0020 0124. Available online: http:/ / www.scotlandspeople.gov.uk (accessed on 20 June 2013).

Births and Baptisms (OPR) Scotland. 1784. Pittenweem, Fife. 452. April 11. HEUGH, James. GROS data 452/00 0020 0134. Available online: http:/ / www.scotlandspeople.gov.uk (accessed on 20 June 2013).

Births and Baptisms (OPR) Scotland. 1786. Pittenweem, Fife. 452. July 9. HEUGH, Thomas. GROS data 452/00 0020 0149. Available online: http:/ / www.scotlandspeople.gov.uk (accessed on 20 June 2013).

Births and Baptisms (OPR) Scotland. 1789. Pittenweem, Fife. 452. May 31. HEUGH, William. GROS data 452/00 0020 0171. Available online: http:/ /www.scotlandspeople.gov.uk (accessed on 20 June 2013).

Births and Baptisms (OPR) Scotland. 1794. Pittenweem, Fife. 452. April 20. HEUGH, George. GROS data 452/00 0020 0011. Available online: http:/ / www.scotlandspeople.gov.uk (accessed on 20 June 2013).

Births and Baptisms (OPR) Scotland. 1812. Pittenweem, Fife. 452. October 16. HEUGH, James. GROS data 452/00 0020 0319. Available online: http:/ / www.scotlandspeople.gov.uk (accessed on 20 June 2013).

Births and Baptisms (OPR) Scotland. 1817a. Pittenweem, Fife. 452. August 3. HEUGH, James. GROS data 452/00 0020 0348. Available online: http:/ / www.scotlandspeople.gov.uk (accessed on 20 June 2013). 
Births and Baptisms (OPR) Scotland. 1817b. Pittenweem, Fife. 452. March 4. CARSTERPHIN, Euphemia. GROS data 452/00 0020 0344. Available online: http: / / www.scotlandspeople.gov.uk (accessed on 20 June 2013). Her grandfather Joseph CARSTERPHIN was married to Janet HEUGH. William HEUGH (uncle or cousin to the father) was a witness.

Births and Baptisms (OPR) Scotland. 1817c. Pittenweem, Fife. 452. March 9. HEUGH, Agnes. GROS data 452/00 0020 0344. Available online: http:/ / www.scotlandspeople.gov.uk (accessed on 20 June 2013).

Births and Baptisms (OPR) Scotland. 1823. Pittenweem, Fife. 452. July 10. HEUGH, Michael. GROS data 452/00 0040 0021. Available online: http:/ / www.scotlandspeople.gov.uk (accessed on 20 June 2013).

Births and Baptisms (OPR) Scotland. 1845. Pittenweem, Fife. 452. September 4. HEUGH, George. GROS data 452/00 0040 0168. Available online: http:/ / www.scotlandspeople.gov.uk (accessed on 20 June 2013).

Births and Baptisms (OPR) Scotland. 1848. Pittenweem, Fife 452. June 6. BLACK, Marjory. GROS data 452/00 0040 0225. Available online: http:/ / www.scotlandspeople.gov.uk (accessed on 20 June 2013).

Births and Baptisms (OPR) Scotland. 1854. Pittenweem, Fife. 452. May 14. HEUGH, Mitchell. GROS data 452/00 0040 0210. Available online: http:/ / www.scotlandspeople.gov.uk (accessed on 20 June 2013).

British Surnames. 2017. Surname statistics for Hughes. Available online: http:/ /www.britishsurnames.co.uk/ surname/hughes/stats (accessed on 30 May 2017).

Census. 1841. Scotland. Pittenweem, Fife. HUGHES, Robt. Age 40. Mid shore Pittenweem. GROS data 452/1/19. Available online: http:/ / www.scotlandspeople.gov.uk (accessed on 20 June 2013).

Census. 1871. Scotland. Pittenweem, Fife, Scotland. HUGHES, George. Age 25. Fisherman. GROS data 452/1/20. Available online: http: / /www.scotlandspeople.gov.uk (accessed on 20 June 2013).

Census. 1881. Scotland. Pittenweem, Fife, Scotland. HUGH, George. Age 35. Fisherman. GROS data 452/1/29. Available online: http:/ / www.scotlandspeople.gov.uk (accessed on 20 June 2013).

Census. 1891. Scotland. Pittenweem, Fife. HUGHES. Robert, Age 20. Fisherman working on own account. GROS data 452/1/25. Available online: http: / / www.scotlandspeople.gov.uk (accessed on 20 June 2013).

Census. 1901. Scotland. Pittenweem, Fife. HUGHES. Robert, Age 30. Fisherman. GROS data 452/1/22. Available online: http:/ / www.scotlandspeople.gov.uk (accessed on 20 June 2013).

Census. 1841a. Scotland. Pittenweem, Fife. HEUGH, Mitchell. Age 18. GROS data 452/00 002/00. Available online: http:/ / www.scotlandspeople.gov.uk (accessed on 20 June 2013).

Census. 1841b. Scotland. Pittenweem, Fife. HEUGH, Elizabeth. Age 85. SCT1841/452.2.51. Freecen. Available online: https: / /www.freecen.org.uk/cgi/search.pl (accessed on 3 March 2012).

Census. 1841c. Scotland. Pittenweem, Fife. HEUGH, Christian. Age 30. SCT1841/452.2.22. Freecen. Available online: https:/ / www.freecen.org.uk/cgi/search.pl (accessed on 3 March 2012).

Census. 1841d. Scotland. Pittenweem, Fife. HEUGH, Thomas. Age 65. SCT1841/452.2.48. Freecen. Available online: https: / / www.freecen.org.uk/cgi/search.pl (accessed on 3 March 2012).

Census. 1841e. Scotland. Pittenweem, Fife. HUGHES, Andrew. Age 65. SCT1841/452.2.20. Freecen. Available online: https: / / www.freecen.org.uk/cgi/search.pl (accessed on 3 March 2012).

Census. 1841f. Scotland. Pittenweem, Fife. HEUGH, Robert. Age 30. SCT1841/452.2.07. Freecen. Available online: https: / /www.freecen.org.uk/cgi/search.pl (accessed on 3 March 2012).

Census. 1841g. Scotland. Pittenweem, Fife. HUGHS, Robert. Age 55. SCT1841/452.2.09. Freecen. Available online: https:/ / www.freecen.org.uk/cgi/search.pl (accessed on 3 March 2012).

Census. 1851. Scotland. Pittenweem, Fife. HEUGH, Thomas. Age 75. SCT1851/452.15.76. Freecen. Available online: https:/ / www.freecen.org.uk/cgi/search.pl (accessed on 3 March 2012).

Census. 1861. Scotland. Clyne, Sutherland. BLACK, Robert. Age 54. GROS data 045.2.1. Available online: http: / / www.scotlandspeople.gov.uk (accessed on 20 June 2013).

David Cook, ed. 1867. Annals of Pittenweem. Being Notes and Extracts from the Ancient Records of That Burgh, 1526-1793. Anstruther: L. Russell.

Coull, James R. 1996. The Sea Fisheries of Scotland: A Historical Geography. Edinburgh: John Donald.

Deaths (SR) Scotland. 1892. Pittenweem, Fife. 452. January 26. HUGHES, George. GROS data 452/00 0002. Available online: http:/ / www.scotlandspeople.gov.uk (accessed on 27 March 2014).

Deaths (SR) Scotland. 1903. St Mary, Dundee. 282. December 4. NAPIER, Marjory Rattray. GROS data 282/2 0695. Available online: http:/ / www.scotlandspeople.gov.uk (accessed on 20 June 2013).

Deaths (SR) Scotland. 1926. Kilrenny, Fife. 438. September 5. SMITH, Mary. GROS data 438/21. Available online: http:/ / www.scotlandspeople.gov.uk (accessed on 20 June 2013). 
Deaths (SR) Scotland. 1930. Pittenweem, Fife. 452. September 27. HUGHES, Robert Black. GROS data 452/00 0014. Available online: http:/ / www.scotlandspeople.gov.uk (accessed on 20 June 2013) Fisherman. Age 60.

Deaths (SR) Scotland. 1860. Pittenweem, Fife. 452. September 9. HEUGHES, William. GROS data 452/00 0006. Available online: http:/ / www.scotlandspeople.gov.uk (accessed on 20 June 2013).

Deaths and Burials (OPR) Scotland. 1774. Tulliallan, Fife. 397. November 30. HEWGH, James. Age 4. GROS data 397/00 0020 0253. Available online: http:/ / www.scotlandspeople.gov.uk (accessed on 20 June 2013).

Deaths and Burials (OPR) Scotland. 1789. Pittenweem, Fife. 452. MUIR, Agnes. June 12. GROS data 452/00 0020 0413. Available online: http:/ / www.scotlandspeople.gov.uk (accessed on 20 June 2013).

Deaths and Burials (OPR) Scotland. 1790. Pittenweem, Fife. 452. January 5. HEUGH, Marjory. GROS data 452/00 0020 0414. Available online: http:/ / www.scotlandspeople.gov.uk (accessed on 20 June 2013).

Deaths and burials (OPR) Scotland. 1818. Pittenweem, Fife. 452. March 3. HEUGH, Mitchel. GROS data 452/20 0447. Available online: http:/ / www.scotlandspeople.gov.uk (accessed on 20 June 2013).

Deaths and Burials (OPR) Scotland. 1841. Pittenweem, Fife. 452. September 28. HEUGHS, George. GROS data 452/00 0040 0507. Available online: http:/ / www.scotlandspeople.gov.uk (accessed on 20 June 2013).

Deaths and Burials (OPR) Scotland. 1842. Pittenweem, Fife. 452. November 25. WATT, Margaret. GROS data 452/00 0040 0513. Available online: http:/ / www.scotlandspeople.gov.uk (accessed on 20 June 2013).

Deaths and Burials (OPR) Scotland. 1844. Pittenweem, Fife. 452. August 8. HEUGH, Elizabeth. GROS data 452/00 0040 0525. Available online: http:/ / www.scotlandspeople.gov.uk (accessed on 20 June 2013).

Deaths and Burials (OPR) Scotland. 1802. Pittenweem, Fife. 452. HEUGH, Christian. OPR452_000_0020_0431Z. Edinburgh: ScotlandsPeopleCentre.

Dobson, David. 2008. A Directory of Seafarers of the East Neuk of Fife 1580-1800: A Genealogical Source Book. St Andrews: David Dobson, p. 32.

Eunson, Eric. 1999. Old Pittenweem. Catrine: Stenlake Publishing.

FamilySearch. Available online: https://familysearch.org/wiki/en/Pittenweem,_Fife,_Scotland_Genealogy (accessed on 20 May 2017).

FindMyPast website. n.d. Available online: http:/ / www.findmypast.co.uk/ (accessed on 3 March 2012).

Fitzpatrick, Linda. 2010. The Real Price of Fish. Catrine: Stenlake Publishing.

Geni. n.d. R-L664 (Y-DNA). Available online: https:/ / www.geni.com/projects/R-L664-Y-DNA/26328 (accessed 31 May 2017).

Gray, Malcolm. 1978. The Fishing Industries in Scotland. 1790-1914. A Study in Regional Adaptation. Aberdeen: Oxford University Press.

Marriages (OPR) Scotland. 1729. Wemyss, Fife. 459. November 28. HEW, James and WOOD, Margery. GROS data 459/00 0050 0274. Available online: http:/ / www.scotlandspeople.gov.uk (accessed on 20 June 2013).

Marriages (OPR) Scotland. 1754. Pittenweem, Fife. 452. November 9. HUGH, Andrew and OLIPHANT, Christian. GROS data 452/00 0020 0015. Available online: http:/ / www.scotlandspeople.gov.uk (accessed on 20 June 2013).

Marriages (OPR) Scotland. 1787. Pittenweem, Fife. 452. November 16. WATT, John and HEUGH, Marjory. GROS data 452/00 0020 0368. Available online: http:/ / www.scotlandspeople.gov.uk (accessed on 20 June 2013).

Marriages (OPR) Scotland. 1789. Leith North, Midlothian. 692. December 4. WAT, James and HUGHS, Margaret. GROS data 692/01 0060 0014. Available online: http:/ / www.scotlandspeople.gov.uk (accessed on 20 June 2013).

Marriages (OPR) Scotland. 1790. Leith South, Midlothian. 692. January 7. HUGH, James and DOEG, Katharin. GROS data 692/00 0110 0155. Available online: http:/ / www.scotlandspeople.gov.uk (accessed on 20 June 2013).

Marriages (OPR) Scotland. 1792. Pittenweem, Fife. 452. February 8. HEUGH, James and OVENSTON, Helen. GROS data 452/00 0020 0376. Available online: http:/ / www.scotlandspeople.gov.uk (accessed on 20 June 2013).

Marriages (OPR) Scotland. 1816. Pittenweem, Fife. 452. September 18. HEUGH, Mitchel and ADAMSON, Anne. GROS data 452/00 0020 0396. Available online: http:/ / www.scotlandspeople.gov.uk (accessed on 20 June 2013).

Marriages (OPR) Scotland. 1817a. Elie, Fife. 427. November 22. HUGHES, George and OLIPHANT, Margaret. GROS data 427/00 0020 0534. Available online: http:/ / www.scotlandspeople.gov.uk (accessed on 20 June 2013). George is "Mariner in Pittenweem".

Marriages (OPR) Scotland. 1817b. Pittenweem, Fife. 452. November 28. HEUGH, George and OLIPHANT, Margaret. GROS data 452/00 0020 0397. Available online: http:/ / www.scotlandspeople.gov.uk (accessed on 20 June 2013).

Marriages (OPR) Scotland. 1845. Pittenweem, Fife. 452. April 18. HEUGHS, Mitchell and ANDERSON, Mary. GROS data 452/00 0040 0354. Available online: http:/ / www.scotlandspeople.gov.uk (accessed on 20 June 2013). 
Marriages (SR) Scotland. 1867. St Andrews and St Leonard's, Fife. 453. September 20. HEUGHES, George and BLACK, Elizabeth Norrie. GROS data 453/31. Available online: http:/ / www.scotlandspeople.gov.uk (accessed on on 20 June 2013).

Marriages (SR) Scotland. 1890. St Mary, Dundee, Angus. 282. September 16. HUGHES, Robert and BUTTERS, Janet. GROS data 282/00 002 0216. Available online: http:/ / www.scotlandspeople.gov.uk (accessed on 20 June 2013).

Martin, Paula. 1991. Pits, Pans and People: The Social Impact of Coal Mining and Salt Making in St Monans and Pittenweem c. 1770-1820. Dundee: Centre for Tayside and Fife Studies.

Merchant Navy records. Britain. 1845-1854. HEUGH, Mitchell. National Archive. TNA. BT 113.48. Available FindMyPast. Available online: http:/ / www.findmypast.co.uk/ (accessed on 1 May 2013).

Merchant Navy Records. 1835-1840a. Hughes, Andrew, b. Pittenweem, age 62. National Archive. TNA. BT112.30. Available online: http:/ / www.findmypast.co.uk/ (accessed on 1 May 2013).

Merchant Navy Records. Britain. 1835-1840b. HUGHS, Robert, age 26. National Archive. TNA. BT112.30. Available online: http:/ / www.findmypast.co.uk/ (accessed on 1 May 2013).

Merchant Navy Records. Britain. 1835-1840c. HUGHES, George. National Archive. TNA. BT112.30. Available online: http:/ / www.findmypast.co.uk/ (accessed on 1 May 2013).

Nadel-Klein, Jane. 1988. Introduction. In To Work and To Weep: Women in Fishing Economies. Social and Economic Papers No. 18. Edited by Jane Nadel-Klein and Donna Lee Davis. St. John's: Institute of Social and Economic Research, Memorial University of Newfoundland.

Nadel-Klein, Jane. 2003. Fishing for Heritage: Modernity and Loss along the Scottish Coast. Oxford: Berg.

Bowie, Neil, and G. W. L. Jackson. 2003. Surnames in Scotland over the Last 140 Years. Available online: https: / / www.nrscotland.gov.uk/statistics-and-data/statistics/statistics-by-theme/vital-events/names / occasional-papers / occasional-paper-no-9-surnames-in-scotland-over-the-last-140-years\#4 (accessed on 30 May 2017).

Powers, Anne M. 2012. A Parcel of Ribbons: Letters of the 18th Century Lee Family in London and Jamaica. Raleigh: Lulu.com.

Reid, Joseph. 2016. Steam Drifters Recalled, Aberdeen to Berwick. Spey Bay: Mr J and Mrs M. Reid.

Swanson, Jenny. 2013. The 1841 Census showed numerous fishermen in Pittenweem: To what extent were they descendants of the few surviving Pittenweem fisher families of the late 18th century? Unpublished P.G. Diploma in Genealogical, Palaeographic and Heraldic Studies dissertation, University of Strathclyde, Glasgow, UK.

Swanson, Jenny. 2014. To What Extent Were Endogamy and Occupational Inheritance Present among the Fishers Recorded in Selected Scottish Communities in 1841? Unpublished M.Sc. dissertation, Genealogical, Palaeographic and Heraldic Studies, University of Strathclyde, Glasgow, UK.

The Statistical Account of Scotland 1791-1799. Vol. 4. p. 369. Pittenweem, County of Fife. Edina.ac.uk. Published 2012. Available online: http:/ / bit.ly /171UQny (accessed on 25 July 2013).

The Statistical Account of Scotland 1791-1799. Vol. 4. Pittenweem, county of Fife. Edina.ac.uk. Published 2012. Available online: http:/ / bit.ly/171UQny (accessed on 25 July 2013).

Wills and Testaments. Scotland. 1831. Cupar Sheriff Court. December 31. Robert HEUGH, Snr, fisher in Pittenweem. SC20/50/6. Available online: http:/ / www.scotlandspeople.gov.uk (accessed on 20 June 2013).

(C) 2017 by the author. Licensee MDPI, Basel, Switzerland. This article is an open access article distributed under the terms and conditions of the Creative Commons Attribution (CC BY) license (http://creativecommons.org/licenses/by/4.0/). 